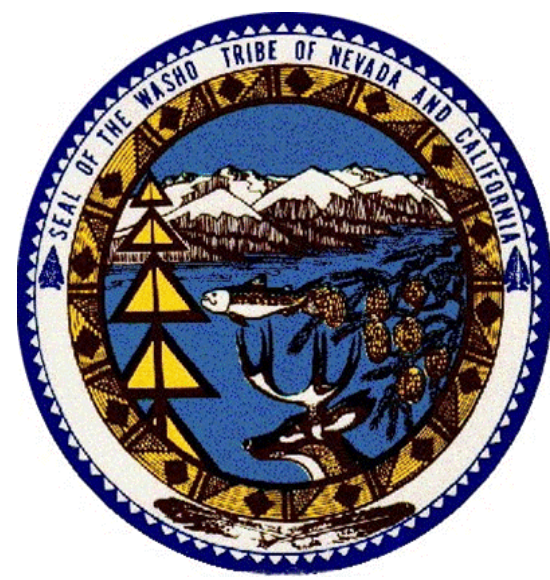

The Washoe Tribe of Nevada \& California

Environmental Protection Department

919 U.S. Hwy. 395 South

Gardnerville, Nevada 89410

\title{
WASHOE WISK'E'EM PROJECT
}

Award Number: DE-EE0003284

Prepared By: Tara Hess-McGeown, Environmental Specialist II

March 26, 2012 


\section{TABLE OF CONTENTS}

EXECUTIVE SUMMARY ........................................................

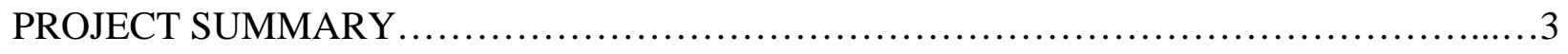

BACKGROUND................................................................

PROJECT OBJECTIVES..........................................................

PROJECT APPROACH..............................................................

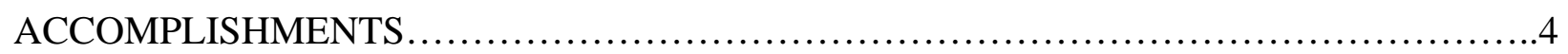

LESSONS LEARNED...........................................................

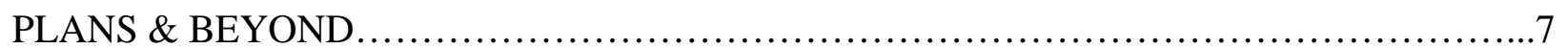

\section{FIGURES}

DRESSLERVILLE COMMUNITY CENTER..........................................5

STEWART COMMUNITY HEAD START ...........................................6 


\section{Executive Summary}

The Washoe Tribe of Nevada and California (Washoe Tribe) does not have a large reservation land base. Rather it has several disconnected parcels (25 excluding allotment lands). A majority of the Tribal members reside within these four parcels: Carson, Stewart, Dresslerville, and Woodfords Communities. Other members live off-reservation. All of these communities are at the base of the Sierra Nevada Mountains.

The Washoe Tribe Wisk'e'em Project (Project) was a Congressionally Directed Project identified for funding in the Energy and Water Development and Related Agencies Appropriations Act, 2010. The Project focused on installing up to four small vertical wind turbines at designated locations on Tribal lands to offset energy costs for the Tribe. The Washoe Tribe will use and analyze data collected from the wind turbines to better understand the wind resource.

\section{Project Summary}

The Washoe Tribe of Nevada and California (Washoe Tribe) will install four small vertical wind turbines at designated locations on Tribal lands to offset energy costs for the Tribe. The Washoe Tribe will use and analyze data collected from the wind turbines to better understand the wind resource. The Washoe Wisk'e'em Project will result in completed installation and power generation from the four wind turbines. This project is in compliance with the Washoe Tribe’s Integrated Resource Management Plan and the Development Planning System.

\section{Background}

The Washoe Tribe of Nevada and California does not have one large reservation land base. Rather it has several (25 excluding allotment lands) disconnected parcels. Four of these parcels are for the Carson, Stewart, Dresslerville and Woodfords Communities where the majority of Tribal members reside. The others live off-reservation. All of these communities are at the base of the Sierra Nevada Mountains.

In September 2008, NVEnergy (formerly Sierra Pacific and Nevada Power) began accepting applications for a new program called WindGenerations. Under this program, an organization can install up to $10 \mathrm{kWh}$ of wind power and receive rebates up to $60 \%$ of total purchase and installation costs. Washoe Environmental Planning Department staff worked with the Washoe Tribe's finance department to determine which community buildings used the most energy and consulted wind maps to analyze the wind resources. Staff then met with all four community councils to present options, answer questions, and receive approval for the wind turbines in each community. In a letter dated November 21, 2008, NVEnergy notified the Washoe Tribe that all six wind turbine proposals were approved to be part of the WindGenerations rebate program. Of the six locations approved, the Washoe Tribe will install four wind turbines, all on public buildings.

\section{Project Objectives}

The Washoe Tribe will conduct a small-application pilot project to demonstrate to tribal members and surrounding communities that wind is a viable alternative energy resource in 
the Carson Valley that can be used to offset energy costs of tribal community buildings. The Washoe Tribe will install four wind turbines, all on public buildings.

\section{Project Approach}

The Washoe Tribe will conduct a small-application pilot project to demonstrate to tribal members and surrounding communities that wind is a viable alternative energy resource in the Carson Valley that can be used to offset energy costs of tribal community buildings. The Washoe Tribe will install four vertical wind turbines at the following sites: Site 1) The Stewart Community Head Start, Site 2) The Carson Community Gym, Site 3) The Dresslerville Community Head Start, and Site 4) The Dresslerville Community Center. As an added benefit, the Washoe Tribe will be able to use data from the wind turbines for a better understanding of the wind resource. These sites have been approved by each Tribal community.

Due to concerns about noise and wildlife, all four of the wind turbines will be vertical-axis turbines. The proposed budget is based on quotes from a local small wind turbine manufacturer. These turbines were originally rated at $1.5 \mathrm{~kW}$. The turbines are now rated at $1.0 \mathrm{~kW}$ but may have an actual output of $1.2 \mathrm{~kW}$. The deliverable for this activity will be the completed installation and power generation from these four wind turbines.

Washoe Environmental Planning Department staff have conducted site assessments of each of the four locations. The US Fish and Wildlife Service were consulted regarding the proposed project activities. No endangered or threatened species were found; therefore, adverse effects on such are unlikely. The project sites are not considered sensitive or critical habitats. Any land clearing will be restricted to the 6' x 6' pad for the turbines, outside of avian breeding season or through clearance from a biologist/environmental specialist.

This project is in compliance with the Washoe Tribe's Integrated Resource Management Plan and the Development Planning System.

\section{Accomplishments}

The Washoe Tribe conducted a small-application pilot project to demonstrate to tribal members and surrounding communities that wind is a viable alternative energy resource in the Carson Valley that can be used to offset energy costs of tribal community buildings.

The Washoe Tribe installed one $1.2 \mathrm{~kW}$ vertical wind turbine at the Dresslerville Community Center located within the community of Dresslerville, Gardnerville, Nevada in Section 15, Township 12 North, Range 20 East, in the SE1/4 of the SE1/4. The second $1.2 \mathrm{~kW}$ vertical wind turbine was installed at the Stewart Head Start Facility located within the community of Stewart, Carson City, Nevada in Section 32, Township 15 North, Range 20 East, in the NW1/4 of the SE1/4.

The installation of the wind turbines were completed in June 2011 and on-line with our local utility provider in August 2011. The two wind turbines have generated a combined total of 83 kilo-watt hours from August 2011 to February 2012 (Dresslerville Community Center - 31 kWh/Stewart Community Head Start - 52 kWh). 

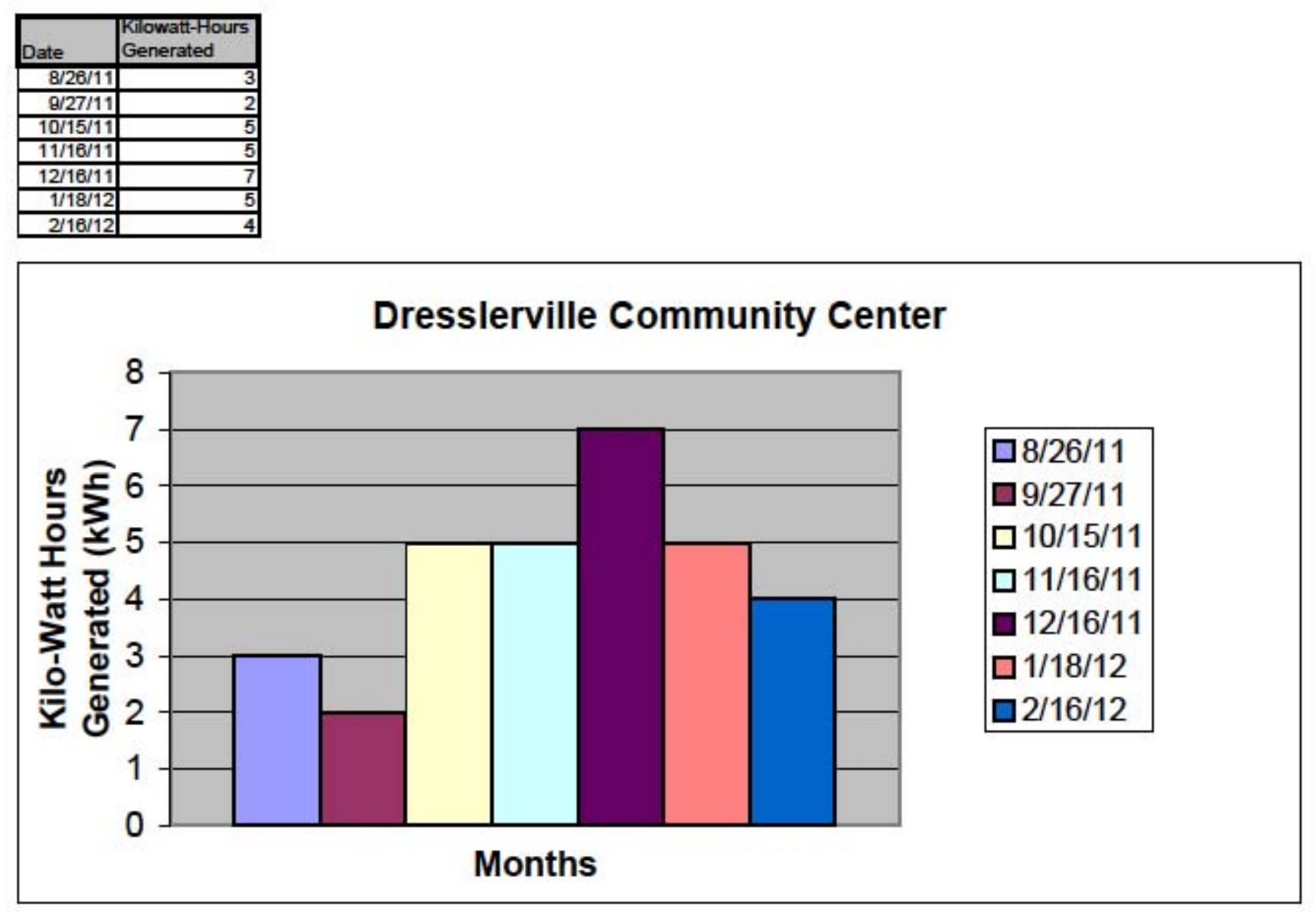


\begin{tabular}{|r|r|}
\hline Date & $\begin{array}{l}\text { Kilowatt-Hours } \\
\text { Generated }\end{array}$ \\
\hline $8 / 13 / 11$ & 0 \\
\hline $9 / 9 / 11$ & 8 \\
\hline $10 / 8 / 11$ & 7 \\
\hline $11 / 8 / 11$ & 4 \\
\hline $12 / 7 / 11$ & 16 \\
\hline $1 / 10 / 12$ & 5 \\
\hline $2 / 9 / 12$ & 12 \\
\hline
\end{tabular}

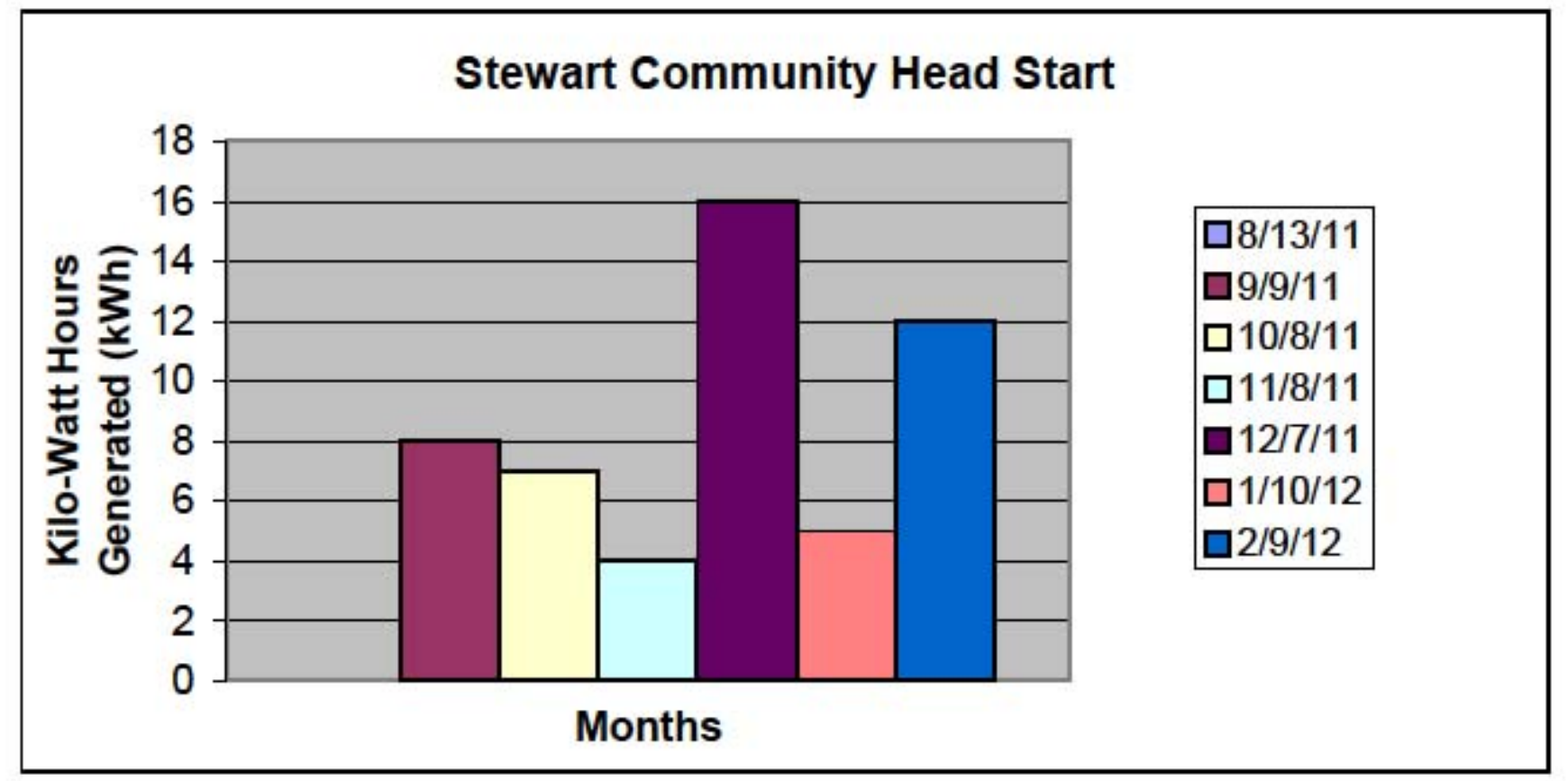


As part of the installation portion of the project the Washoe Tribe participated with the local utility provider, NV Energy's (formerly Sierra Pacific and Nevada Power) Renewable Generations Program under the Wind Generation Program to receive rebate incentives. Under this program, an organization can install up to $10 \mathrm{kWh}$ of wind power and receive rebates up to $60 \%$ of total purchase and installation costs. The Washoe Tribe received approximately 2400 kilowatts of capacity at $\$ 4.00$ per watt AC.

\section{Lessons Learned}

In addition to demonstrating to tribal and surrounding communities that wind is a viable alternative energy resource, the Washoe Tribe is able to use and analyze data collected from the wind turbines to better understand the wind resource. Unfortunately, at this time we only have approximately six months worth of wind data to share. The Windspire wind data is collected using the Windsync software.

The Washoe Tribe installed two of the approved four wind turbines. The decision not to install wind turbines at the other two community locations; the Dresslerville Community Head Start Facility and the Carson Community Gym was due to the lack of funding. During project negotiations the cost of the materials increased dramatically resulting in a decrease in the number of wind turbines installed.

\section{Plans and Beyond}

The Washoe Tribe does not have any plans at this point to move forward on installing additional wind turbines. However, we have recently reached out to foundations in hope of fund raising additional dollars to assist with installing two more Windspire wind turbines in our Woodfords and Carson Communities. 